\title{
Effect of Pentanol-Diesel Fuel Blends on Thermo-Physical Properties, Combustion Characteristics, Engine Performance and Emissions of a Diesel Engine
}

\author{
Zuhaira Abdullah ${ }^{1}$, Hazrulzurina Suhaimi ${ }^{1}$, Adam Abdullah ${ }^{1,2 *}$ \\ Mohd Firdaus Taufik ${ }^{1}$ and Anes G. Mrwan ${ }^{1}$ \\ ${ }^{1}$ Faculty of Mechanical Engineering, Universiti Malaysia Pahang, \\ 26600 Pekan Pahang, Malaysia \\ ${ }^{2}$ Automotive Engineering Centre, Universiti Malaysia Pahang, \\ 26600 Pekan Pahang, Malaysia \\ Email: adam@ump.edu.my \\ Phone: +6-09-4246353; Fax: +6-09-4246345
}

\begin{abstract}
The objective of this study is to analyse the effect of pentanol-diesel fuel blends on thermo-physical properties, combustion characteristics, engine performance, and emissions of a diesel engine. The experimental tests were performed using YANMAR TF120M single-cylinder, direct-injection diesel engine. The fuel tests were evaluated using $5 \%, 10 \%$, and $20 \%$ pentanol added onto diesel fuel (DF), denoted as PE5, PE10 and PE20, respectively, to produce pentanol-diesel fuel blends at a constant engine speed of $1800 \mathrm{rpm}$ under various engine loads. Based on the results, thermo-physical properties show that the calorific value, density, and kinematic viscosity were reduced by $8.12 \%$, $1.2 \%$, and $12 \%$ for PE20. In addition, at $25 \%$ engine load, the in-cylinder pressure of PE5, PE10, and PE20, were reduced by $1.76 \%, 3.43 \%$, and $6.54 \%$, respectively, compared to DF. Furthermore, maximum heat release rate of PE5, PE10, and PE20 were reduced by $6.74 \%, 7.50 \%$, and $18.54 \%$, respectively, compared to DF at $25 \%$ engine load. Moreover, at $25 \%$ engine load, the brake specific fuel consumption of PE5 showed better performance result due to fuel consumptions usage being reduced by $20.83 \%$. Conversely, brake thermal efficiency increased by $11.2 \%$, at $25 \%$ engine load for PE5. $\mathrm{CO}$ and $\mathrm{CO}_{2}$ emissions decreased by $9.99 \%$ and $3.2 \%$, respectively, at $100 \%$ engine load of PE20.
\end{abstract}

Keywords: Diesel; long-chain alcohol; combustion; performance; emission.

\section{INTRODUCTION}

The diesel engine is well known for its energy efficiency and high performance in combustion. Furthermore, a diesel engine is also known for its advantages including high torque, high efficiency, and reliability with low operating cost. The diesel engine is mainly being used in various sectors such as automotive transportation, heavy industry machine application, agricultural machinery and marine transportation [1, 2]. However, diesel fuel (DF) is a non-renewable fossil fuel which will continue to deplete over time as a result of its excessive production and use [3]. Furthermore, the exhaust emissions from DF combustion contribute to various problems related to human health and to the environment. Exhaust emissions such as carbon monoxide (CO), hydrocarbon (HC), particulate matter $(\mathrm{PM})$ and nitrogen oxides $\left(\mathrm{NO}_{\mathrm{x}}\right)$ are among the harmful substances emitted by a diesel engine. 
Study on alternative fuels have been popular among researchers around the world to minimise the usage of DF and to reduce exhaust emissions [4, 5]. Biodiesel is one alternative fuel that has the potential to replace the DF due to its renewability, biodegradability, and better fuel properties [6,7]. Biodiesel can be derived from vegetable oil and animal fats. There are many alternative fuels reported that have potentials to minimise usage of DF such as emulsion fuel, waste cooking oil, alcohol-diesel fuel, insect-fuel and synthetic fuel [8-10]. Currently, alcohol-diesel fuel blends have also received wide interests among researchers to reduce dependency on fossil fuels. In fact, alcohol-diesel fuel blends also show potential to support energy demand and to regulate exhaust emissions [11].

Alcohol can be divided into two categories, namely short-chain alcohol and longchain alcohol. Carbon with less than five carbon atoms are categorised as short-chain alcohol, while carbon with more than five carbon atoms are known as long-chain alcohol. The short-chain alcohol such as methanol, ethanol, and propanol are well known for its character as an oxygenated liquid that could increase oxygen content in the fuel blend, thus performing better combustion and reducing exhaust emission [12]. A study by Rashedul et al. [13] reported that mixing n-butanol into DF decreased brake specific fuel consumption (BSFC) by $6.25 \%$ and increased brake thermal efficiency (BTE) by $5.81 \%$ compared to DF. However, due to n-butanol and DF mixture phase separation problem, the authors indicated the application of platinum as a based additive to stabilise the bonding mixture of n-butanol-diesel fuel. Rakopoulus et al. [14] used $20 \%$ of n-butanol with cottonseed biodiesel and reported that the $\mathrm{NO}_{\mathrm{x}}$ and $\mathrm{CO}$ emissions decreased by 14.28 $\%$ and $4.13 \%$, respectively. Nevertheless, the authors also indicated some drawbacks of short-chain alcohol-biodiesel fuel blends such as low calorific value, low cetane index, poor blending solubility, and long ignition delay. In another study, Taghizadeh et al. [15] investigated the effect of ethanol-diesel fuel blends on performance, combustion, vibration, and engine knocking. The authors' results showed that BTE decreased by 6.68 $\%, 6.97 \%$, and $5.23 \%$ for $8 \%, 10 \%$, and $12 \%$ ethanol, respectively, compared to DF. BTE decreased due to phase separation problems of ethanol-diesel fuel blends. Moreover, by increasing the concentration of ethanol by more than $8 \%$, it raised the ignition delay by $45.67 \%$ and increased the irregularity by $70.91 \%$ of the in-cylinder pressure [15].

Long-chain alcohol-diesel fuel blends have potential as an attractive alternative fuel to meet energy demand and reduce emission, thus overcoming the disadvantages of the short-chain alcohol-diesel fuel blend. Long-chain alcohols such as pentanol, hexanol, and octanol show high potential as fuel additives in numerous studies [16, 17]. The utilisation of long-chain alcohol enriched with oxygen content can improve thermophysical properties such as density, cetane number, flashpoint, viscosity and boiling point. In addition, long-chain alcohol-diesel fuel blend shows no phase separation and can normally run without any additional additive to avoid phase separation [18]. Wei et al. [19] gave a comprehensive review on the effect of n-pentanol addition on combustion, performance and emission characteristics of a direct-injection diesel engine. The authors concluded that n-pentanol showed higher peak pressure release rate by $47.98 \%, 48.33 \%$, and $46.63 \%$ for $10 \%, 20 \%$ and $30 \%$ of pentanol-diesel fuel blends, respectively, compared to DF. This is due to the long ignition delay for pentanol-diesel fuel blends that enable more amount of fuel burned in the premixed combustion phase. BSFC increased by $0.83 \%, 2.71 \%$, and $6.27 \%$ with the concentration increment of n-pentanol. The authors also indicated that the $\mathrm{CO}$ emission decreased by $25 \%$ for $10 \%$ of n-pentanol at 7.10 bar engine load. In a different study, Kumar et al. [20] demonstrated an effect of a sustainable n-octanol-diesel fuel blend on combustion, performance, and emissions with 
the addition of exhaust gas recirculation (EGR) modes. The authors found that BTE increased by $10.25 \%$, while BSFC decreased by $20 \%$ with increasing the concentration of n-octanol. Both results indicated an improved combustion efficiency contributed by increasing oxygen content in the fuel blends which produced more power output. Moreover, $\mathrm{NO}_{\mathrm{x}}$ emission decreased by $8.74 \%$ for $30 \%$ of n-octanol concentration at 30 $\%$ EGR condition. $\mathrm{NO}_{\mathrm{x}}$ and smoke opacity reduced with a higher concentration of $\mathrm{n}-$ octanol due to the dominating influence of fuel-bound oxygen content in the n-octanoldiesel fuel blend.

Although there were many researchers studying on the long-chain alcohol-diesel fuel blends, none of them focused on low-volume ratio of long-chain alcohol in diesel blends. Most of the studies focused on the alcohol volume ratio higher than $10 \%$. The previous study on pentanol-diesel fuel blends done by Saravanan et al. [21] tested four pentanol-diesel fuel blends of $10 \%, 20 \%, 30 \%$, and $45 \%$. In addition, De Poures et al. [11] researched on hexanol-diesel fuel blends of $10 \%, 20 \%$, and $30 \%$ volume ratio. Despite many research done on long-chain alcohol-diesel fuel blend combustion analysis, none of them investigated on $5 \%$ long-chain alcohol volume ratio. Therefore, to fill up this gap, this research was conducted for $5 \%, 10 \%$ and $20 \%$ of pentanol-diesel fuel blends with complete analysis including combustion characteristics, engine performance and exhaust emissions. Pentanol of $5 \%, 10 \%$ and $20 \%$ namely PE5, PE10, and PE20 were blended with DF and tested with YANMAR TF120M single cylinder, directinjection diesel engine. Experiments were conducted on five engine loads of $0 \%, 25 \%$, $50 \%, 75 \%$, and $100 \%$ at a constant engine speed of $1800 \mathrm{rpm}$.

\section{EXPERIMENTAL SETUP AND TEST PROCEDURE}

\section{Preparation of Test Fuel}

A standard fuel DF JIS\#2 (Japanese Industrial Standard) and long-chain alcohol pentanol were employed in this experiment. In addition, pentanol was $100 \%$ fully dissolved in DF to form a stabilised pentanol-diesel fuel blend. No additive was added in order to stabilise and avoid phase separation. Three fuel blends were prepared with pentanol 5\%,10\%, and $20 \%$ by volume mixed with DF and named as PE5, PE10, and PE20, accordingly. Ultrasonic emulsifier (Hielscher UP400S) was employed to mix the fuel blends at $70 \%$ amplitude and 0.5 cycle for 2 minutes. The mixing process time was controlled not to exceed 2 minutes in order to prevent damaging the chemical properties and elements of the fuel. The temperature was kept between $30^{\circ} \mathrm{C}-32^{\circ} \mathrm{C}$ to avoid damaging the pentanol elements. The flashpoint for pentanol is $33^{\circ} \mathrm{C}$. The procedure was repeated until 6 liters of fuel mixtures were obtained.

\section{Test Engine and Instrumentation}

In this experiment, YANMAR TF120M single cylinder, direct-injection diesel engine was utilised for running the fuel blends. The diesel engine is a direct injection watercooled engine with fuel injection that occurs at $17^{\circ} \mathrm{CA}$ before the top dead centre (TDC). The specifications of the diesel engine are as listed in Table 1. Figure 1 shows the schematic diagram of the engine test with the necessary equipment that are connected to the dynamometer. The dynamometer used in this experiment was eddy current dynamometer model BD $15 \mathrm{~kW}$ manufactured by Focus Applied Technology, with SAE J1349 Standard Engine Power Test Code for a diesel engine. The dynamometer was 
mounted in spherical bearings and fitted directly to the diesel engine. The engine setup was equipped with a data acquisition unit (DAQ) by DEWESoftX2 engineering software. A fiber optic transducer, type OPTRAND C82294-Q was connected to SIRIUS i-HS to measure the data of engine combustion characteristics. The engine testing was repeated three times for each fuel.

Table 1. Engine specifications.

\begin{tabular}{lc}
\hline & Specification \\
\hline Engine type & YANMAR TF120M \\
Number of cylinder & 1 \\
Bore and stroke & $92 \times 96 \mathrm{~mm}$ \\
Displacement & $0.638 \mathrm{~L}$ \\
Compression ratio & 17.7 \\
Injection timing & $17^{\circ} \mathrm{bTDC}$ \\
Continuous output & $10.5 \mathrm{HP}$ at $2400 \mathrm{rpm}$ \\
Rated output & $12 \mathrm{HP}$ at $2400 \mathrm{rpm}$ \\
Cooling system & Water-cooled \\
\hline
\end{tabular}

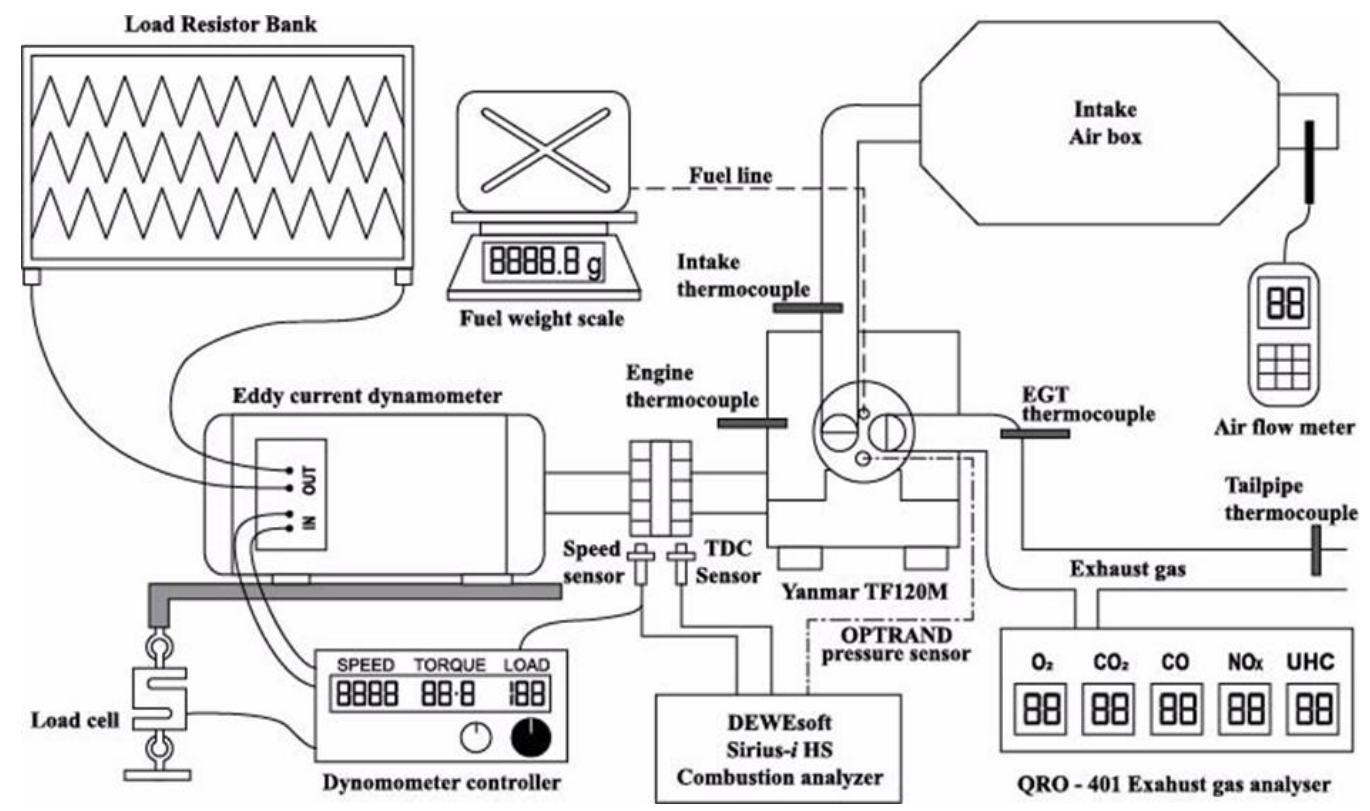

Figure 1. Schematic diagram of experimental setup for single-cylinder diesel engine.

\section{Engine Test Cycle and Test Procedures}

The engine works on four-stroke cycle and operates with low engine load range from 0 $7 \mathrm{Nm}$, in medium engine load range from 14-21 Nm, and in high engine load range from 21-27 Nm. These engine load ranges from $0 \%$ to $25 \%, 50 \%, 75 \%$ and $100 \%$ at a constant engine speed of $1800 \mathrm{rpm}$. This experiment was repeated three times to ensure the data collected was constant and validated. The diesel engine was warmed up with DF for about 10 minutes to stabilise the fuel blend operating system. At every test fuel change, the engine was flushed with DF to pre-empt the waste of fuel blend. 


\section{Thermo-physical Specifications}

The pentanol-diesel fuel blend of thermo-physical properties were characterised strictly following the ASTM standard. The thermo-physical properties for equipment used and type of ASTM are shown in Table 2. Referring to Table 3, when compared to DF, the calorific value for PE5, PE10, and PE20 were reduced by $3.17 \%, 3.73 \%$, and $8.12 \%$, respectively. Furthermore, the density shows significant reduction at increasing pentanol concentration in fuel blends. The density was reduced by $0.12 \%, 0.84 \%$ and $1.20 \%$ for PE5, PE10 and PE20, respectively, compared to DF.

Table 2. Properties tested and equipment type

\begin{tabular}{lcc}
\hline Properties & ASTM & Equipment \\
\hline Calorific value & ASTM D6751 & Bomb calorimeter, Parr 6772 \\
Density & ASTM D1298 & Analytical balancer, GH-252 \\
Kinematics viscosity & ASTM D445 & Viscometer, GD-265D \\
\hline
\end{tabular}

Table 3. Thermal-physical properties

\begin{tabular}{lccccc}
\hline Fuel Properties & Unit & DF & PE5 & PE10 & PE20 \\
\hline Calorific value & $\mathrm{MJ} / \mathrm{kg}$ & 48.29 & 46.76 & 46.49 & 44.37 \\
Density & $\mathrm{kg} / \mathrm{m}^{3}$ & 0.832 & 0.831 & 0.825 & 0.822 \\
Kinematic viscosity & $\mathrm{mm}^{2} / \mathrm{s}$ & 3.5 & 3.19 & 3.14 & 3.08 \\
\hline
\end{tabular}

\section{RESULTS AND DISCUSSION}

\section{Combustion Characteristics - In-Cylinder Pressure and Heat Release Rate}

The in-cylinder pressure and heat release rate (HRR) of all fuel blends (DF, PE5, PE10, and PE20) were plotted against the crank angle (CA) at different engine loads and constant engine speed at $1800 \mathrm{rpm}$. Figure 2 shows the in-cylinder pressure and HRR increasing as the engine load increases. Referring to Figure 2(a), the in-cylinder pressure for all test fuels show peak pressure at $4^{\circ} \mathrm{CA}$. The ignition delay of PE5, PE10, and PE20 fuel blends does not show much difference as compared to DF. At low engine load (25 $\%$ ), the in-cylinder pressure decreased by $1.76 \%, 3.43 \% \%$, and $6.54 \%$ for PE5, PE10, and PE20, respectively, compared to DF. Maximum reduction of $6.54 \%$ was shown for PE20. This is because the density of PE20 is lower by $0.822 \mathrm{~kg} / \mathrm{m}^{3}$ as compared to DF, which results from low premixed combustion. In addition, the low kinematic viscosity by $3.08 \mathrm{~mm}^{2} / \mathrm{s}$ of PE20 has increased the fuel-air mixture during ignition delay to complete the combustion phase. Figure 2(b) demonstrates that at $50 \%$ engine load, the in-cylinder pressure decreases by $1.14 \%, 0.24 \%$, and $2.46 \%$ for PE5, PE10, and PE20, respectively.

Referring to the figure, the in-cylinder pressure of PE10 attains close to DF. Figure 2(c) shows at high engine load of $100 \%$, PE5, PE10, and PE20 increases by $1.24 \%, 3.76$ $\%$, and $14.71 \%$, respectively. The maximum increase of in-cylinder pressure by $14.71 \%$ occurs at high engine load (100\%) for PE20. The increase can be explained due to the presence of pentanol which contained oxygen that carried a strong premixed combustion phase and increased by 76.97 bar at peak pressure. In addition, the ignition delay was shorter, and the amount of fuel burned in the combustion chamber was released in a large 
amount of power output, thus showing better atomisation. The same result was found by Imdadul et al.[22] that in-cylinder pressure of long-chain alcohol was higher than DF.

The HRR in Figure 2(a) - 2(c) shows results of different fuel blends at different engine loads for a constant engine speed of $1800 \mathrm{rpm}$. The graphs show the highest HRR occurring at $2^{\circ} \mathrm{CA}$ plotted against varied fuel blends. Figure 2(a) shows the result for low engine load (25\%); the graph shows that PE5, PE10, and PE20 reduces by $6.74 \%, 7.50$ $\%$, and $18.54 \%$, respectively. The ignition delay of fuel blends was slightly longer than DF, due to the presence of oxygen content in the pentanol-diesel fuel blends. With the addition of pentanol, the higher oxygen content causes increased HRR value as more fuel shall be required to rapidly combust during longer ignition delay. Balamurugan et al. [23] reported that alcohol-diesel fuel blends have high HRR compared to DF.

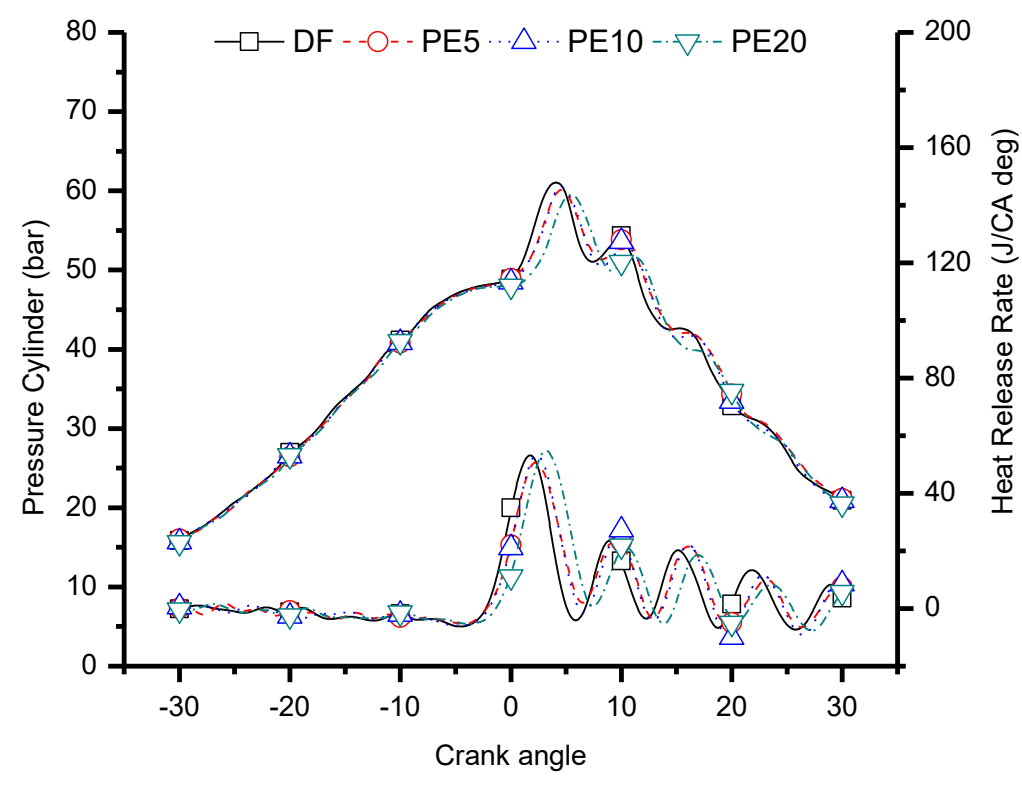

(a) $25 \%$ engine load.

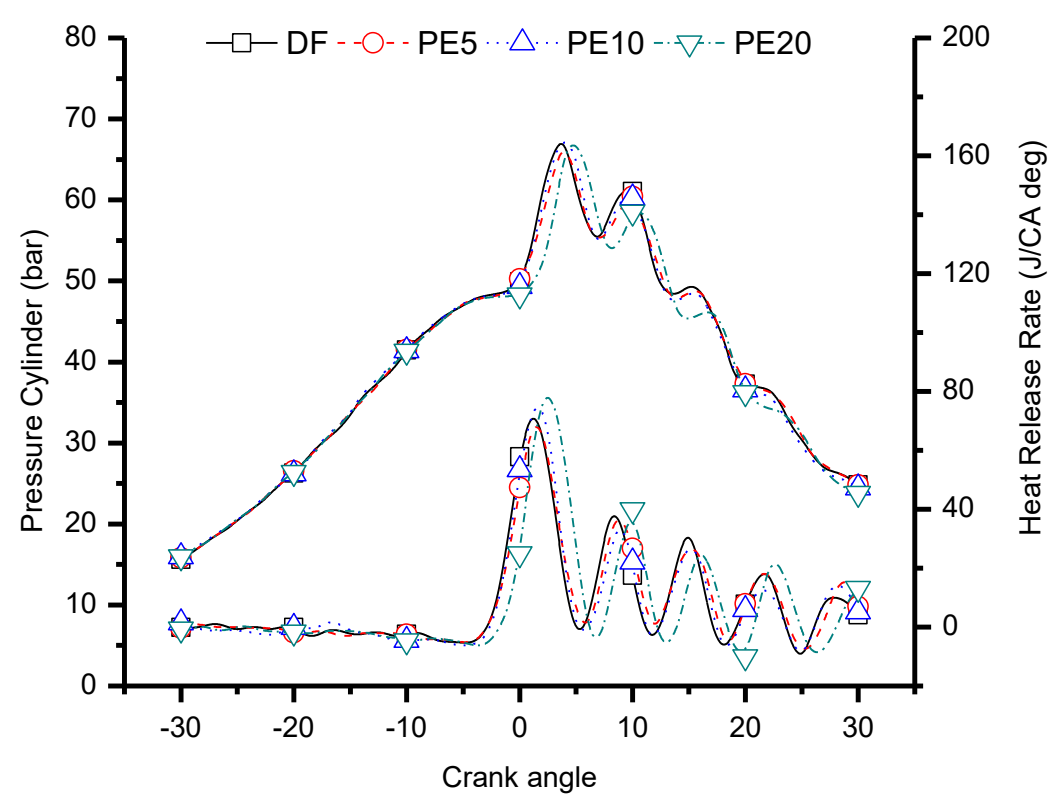

(b) $50 \%$ engine load. 


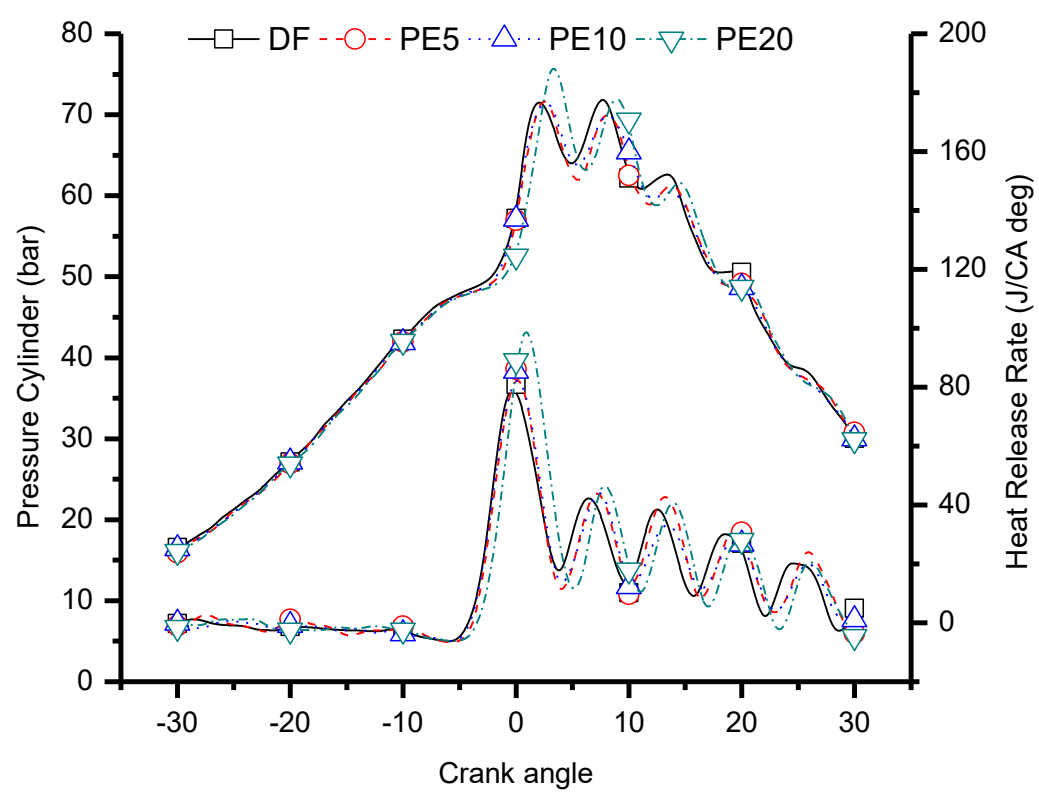

(c) $100 \%$ engine load

Figure 2. Combustion pressure and heat release rate in varied engine load of DF and fuel blends at a constant engine speed of $1800 \mathrm{rpm}$.

Figure 2(b) demonstrates that HRR of PE5, PE10, and PE20 increases by $1.82 \%$, $14.03 \%$, and $17.19 \%$, respectively, compared to DF, at $50 \%$ engine load. Referring to the graph, HRR increases due to the better fuel-air mixing process and better atomisation by the addition of pentanol. In addition, according to Figure 2(c) at high engine load (100 $\%$ ), the HRR measured is higher compared to DF by $8.01 \%, 20.54 \%$, and $80.02 \%$ for PE5, PE10, and PE20, respectively. The important fact is HRR of PE20 is higher by 80.02 $\%$ than DF due to the increase in oxygen content in the pentanol-diesel fuel blend. Moreover, HRR peak in the premixed combustion period increases by $7.63 \%$ and the CA has further shifted away from $1^{\circ} \mathrm{CA}$ to $2^{\circ} \mathrm{CA}$.

Furthermore, Sathiyamoorthi et al. [24] supported that the presence of oxygen content in fuel blends affects to lengthen the ignition delay, thus increasing the peak HRR value for fuel blends. Long ignition delay for fuel blends results in more fuel being burned in the premixed combustion phase.

\section{Engine Performance - Brake Specific Fuel Consumption and Thermal Efficiency}

Figure 3 illustrates the brake specific fuel consumption (BSFC) comparison between DF, PE5, PE10, and PE20 against various engine loads. In general, BSFC shows a linear decrease for all fuel blends as the engine load increases. The most significant results reveal that at low engine load (0-25\%), alcohol-diesel fuel blends show higher BSFC compared to DF, indicating incomplete and low-efficiency combustion.

Meanwhile, low BSFC at high engine load (50-100 \%) shows improvement at high in-cylinder pressure thus leading to a complete and high-efficiency combustion. Referring to Figure 3, BSFC is improved by $10.79 \%$ and $20.83 \%$ for PE5 at $0-25 \%$ engine load, but at high engine load $(100 \%)$ the fuel consumption usage increases by $43.45 \%$ for PE10. This is due to the lower kinematic viscosity and density of pentanoldiesel fuel blends. In addition, lower BSFC is achieved with the addition of pentanol due 
to the increase of diffusion rates of the fuel vapour inside the combustion chamber, which promotes air-fuel mixture preparation before ignite. The fuel blend has a shorter ignition delay that leads to better combustion efficiency, thus affecting the reduction of emission. The BSFC of PE10 was increased by $3.10 \%, 22.61 \%$, and $43.45 \%$ for engine loads of $50 \%, 75 \%$, and $100 \%$, respectively, compared to DF. Similar results were also reported by He et al. [25]. The authors reported that the trend was related to high oil temperature and low excess air ratio at high engine load condition leading to the increase of BSFC. The lubrication and combustion led to an increase in BFSC.

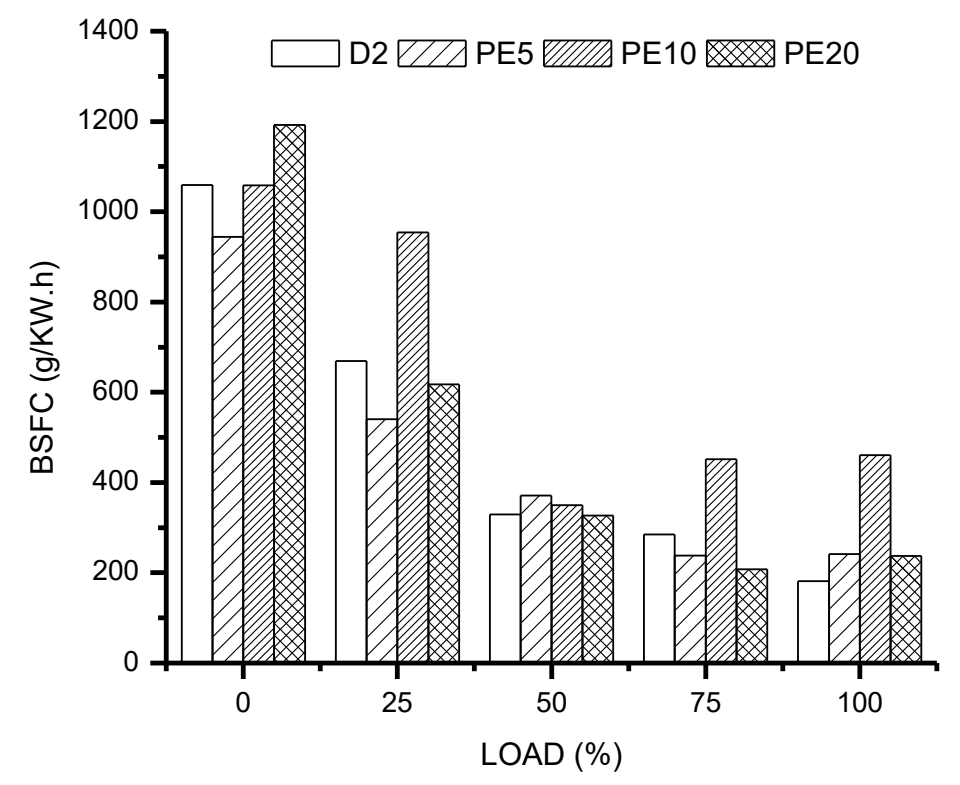

Figure 3. The effect of BSFC for diesel fuel and fuel blends at constant engine speed of $1800 \mathrm{rpm}$ and at varied load condition.

The BTE was plotted in Figure 4 for all fuel blends against engine loads at a constant engine speed at $1800 \mathrm{rpm}$. In general, the results show that BTE increases as the engine load increases. As seen in the figure, at PE5, BTE increases by $20.20 \%$ and 11.20 $\%$ for $0 \%$ and $25 \%$ engine loads, respectively, compared to DF. This is due to the fact that, when pentanol was added onto DF, the high oxygen content formed in a pentanoldiesel fuel blend will lead to better atomisation. Lapuerta et al. [26] concluded that the addition of a long-chain alcohol such as pentanol, hexanol, and octanol into DF led to oxygen enrichment, higher flame speed and improved spray characteristics of the fuel combustion. Moreover, fuel blends show a longer ignition delay compared to DF, which can be associated with the fuel blends' low cetane number, improving the combustion and increasing the BTE. However, PE10 shows BTE reducing by $2.23 \%, 1.75 \%$, and 3.07 $\%$ for $50 \%, 75 \%$, and $100 \%$ engine loads respectively, compared to DF. This is due to the calorific value of the fuel blends decreasing by $46.49 \mathrm{MJ} / \mathrm{kg}$ while increasing the concentration of pentanol ratio.

PE10 has a maximum reduction by $3.07 \%$ of BTE due to poor atomisation during the premixed combustion phase. At maximum engine load (100\%), PE10 slightly reduced BTE as the amount of oxygen content obtainable for combustion of the fuel blends decreased due to replacement by the exhaust gas. A similar result was also reported by Sundar et al. [27] that with $10 \%$ addition of hexanol, fuel blends decreased by $33.9 \%$ at maximum break power due to the decreased amount of oxygen. 


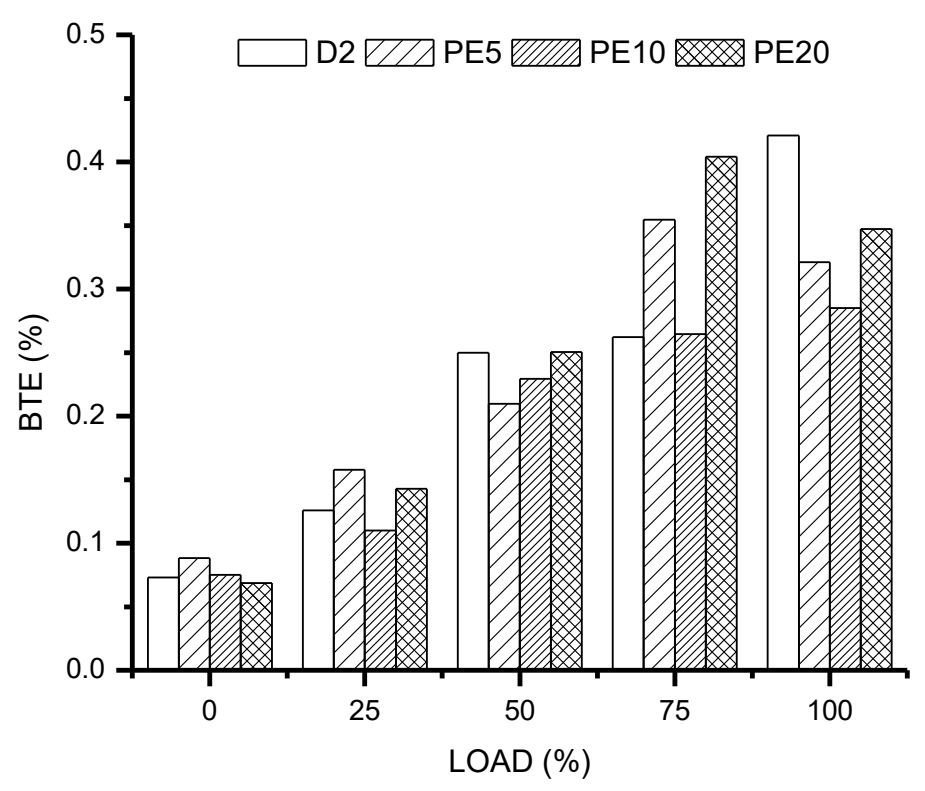

Figure 4. The effect of BTE for diesel fuel and fuel blends at constant engine speed of $1800 \mathrm{rpm}$ in varied load conditions

\section{Exhaust Gas Emissions Measurements}

The exhaust emission $\left(\mathrm{CO}, \mathrm{CO}_{2}, \mathrm{HC}\right.$, and $\left.\mathrm{NO}_{\mathrm{x}}\right)$ were measured using the gas analyser model QROTECH. The graph was plotted between DF and fuel blends of PE5, PE10, and PE20 against engine loads at constant engine speed of $1800 \mathrm{rpm}$.

\section{Carbon monoxide (CO) emissions}

The formation of $\mathrm{CO}$ emissions is mainly caused by uncontrolled air-fuel ratio of the mixture and incompleteness of the combustion process. Figure 5 indicates that the formation of $\mathrm{CO}$ increases as the engine load increases. Clearly, PE5 shows the CO emission increasing by $33.33 \%$ and $20.01 \%$ for $75 \%$ and $100 \%$ engine loads, respectively, compared to DF. The increase in $\mathrm{CO}$ emission due to low calorific value of fuel blends affected the engine performance. Suhaimi et al. [28] found similar results, showing that the higher latent heat of vaporisation of pentanol occurred during the increment of in-cylinder temperature as engine loads increased. However, PE20 had successfully lowered CO emission by $9.99 \%$ at high engine load (100\%) due to the oxygen content of pentanol and good vaporisation. This is due to the higher concentration of pentanol that gives an increased amount of oxygen content in the fuel blend leading to complete combustion and thus low CO emission. With lower density of PE20 than that of DF, pentanol evaporates easily into the cylinder, thus decreasing the spray atomisation length [29]. The same result was found by Phoon et al. [30] where $2 \%$ of ethanol 2-EHN enriched oxygen content helped to improve and reduce $\mathrm{CO}$ emission. 


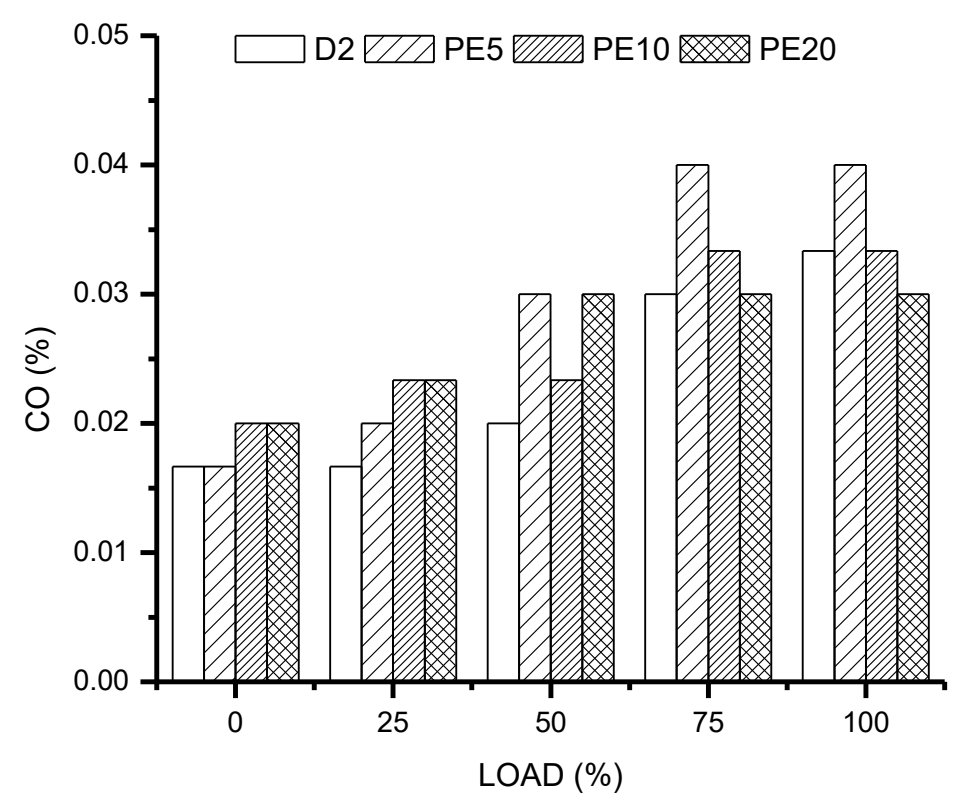

Figure 5. Variation of $\mathrm{CO}$ emission for diesel fuel and fuel blends

\section{Carbon dioxide $\left(\mathrm{CO}_{2}\right)$ emission}

Figure 6 shows the $\mathrm{CO}_{2}$ emission curve under variable engine loads at constant engine speed $1800 \mathrm{rpm}$. The presence of $\mathrm{CO}_{2}$ emissions occurs with the excess of oxygen content, where hydroxyl radical $(\mathrm{OH})$ is one of the primary oxidising agents that convert $\mathrm{CO}$ into $\mathrm{CO}_{2}$. In general, the graph shows that $\mathrm{CO}_{2}$ decreases slightly as the engine load increases. Among the fuel blends, $\mathrm{CO}_{2}$ emission was reduced by $0.92 \%, 2.76 \%$, and $3.22 \%$ for PE5, PE10 and PE20, respectively, compared to DF at $100 \%$ engine load. $\mathrm{CO}_{2}$ emissions was slightly reduced for all fuel blends at various engine loads compared to DF.

The main reason is supported by Ileri et al. [16] that increased oxygen and hydrogen molecules in fuel structures will cause reduction of $\mathrm{CO}_{2}$ emission. Chemical structures of fuel blends are considered due to pentanol having low carbon atoms per unit volume. The increase of oxygen content and hydrogen molecules in fuel blends will decrease the formation of $\mathrm{CO}_{2}$ emission. Furthermore, Machacon et al. [31] concluded that higher latent heat of vaporisation of long-chain alcohol caused a lower operating temperature occurring in diesel engine thereby reducing the $\mathrm{CO}_{2}$ emission. 


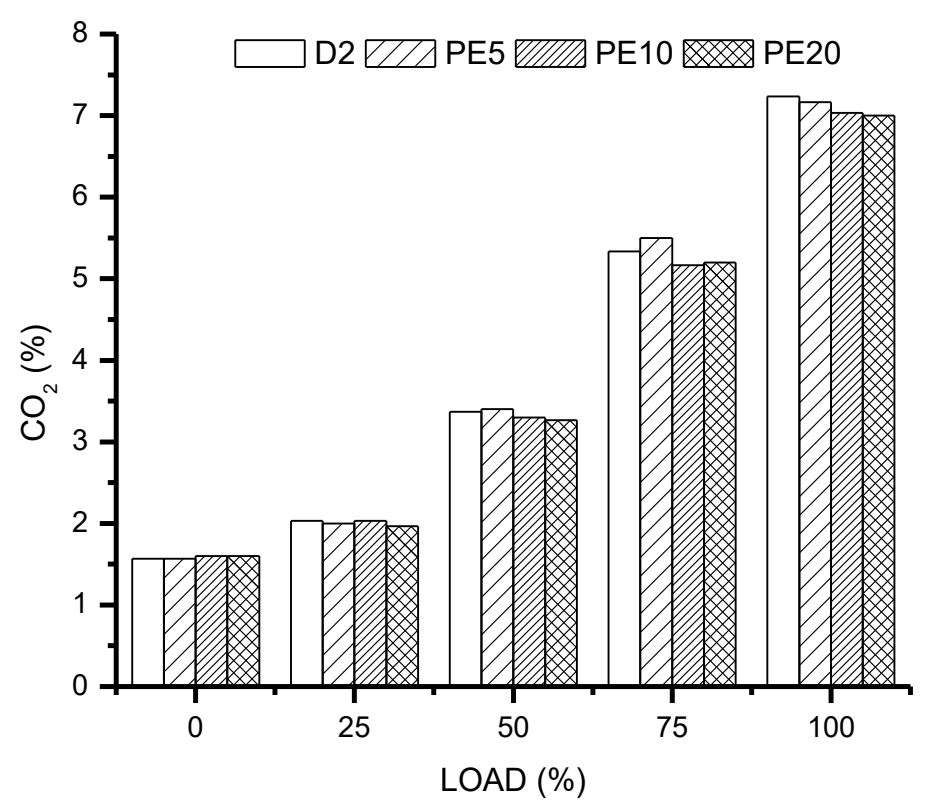

Figure 6. Comparison of $\mathrm{CO}_{2}$ emission for diesel fuel and fuel blends.

\section{Hydrocarbon (HC) emission}

The total amount of unburned hydrocarbon (HC) for fuel blend is plotted in Figure 7. In general, HC emission decreases as the engine load increases. Referring to the figure, HC emission at low engine load (0 \%) for PE5, PE10, and PE20 increases by $16.98 \%, 24.14$ $\%$, and $39.72 \%$, respectively, compared to DF. At high engine load (100\%), HC emission of the fuel blends increases by $22.22 \%, 41.67 \%$, and $58.82 \%$ for PE5, PE10, and PE20, respectively, compared to DF. This finding is consistent with a study by Rakopoulus et al. [32] who operated a heavy-duty diesel engine. The authors reported that HC emission was higher for butanol-diesel fuel blends compared to DF. In addition, this led to higher $\mathrm{HC}$ emission due to the high heat of vaporisation and the increasing lean outer flame zone. Consistent with the results by Cheung et al. [33], the oxygen content of the test fuel blends increased when n-pentanol was added. The oxidation of unburned $\mathrm{HC}$ emission occurred at relatively high in-cylinder temperature. 


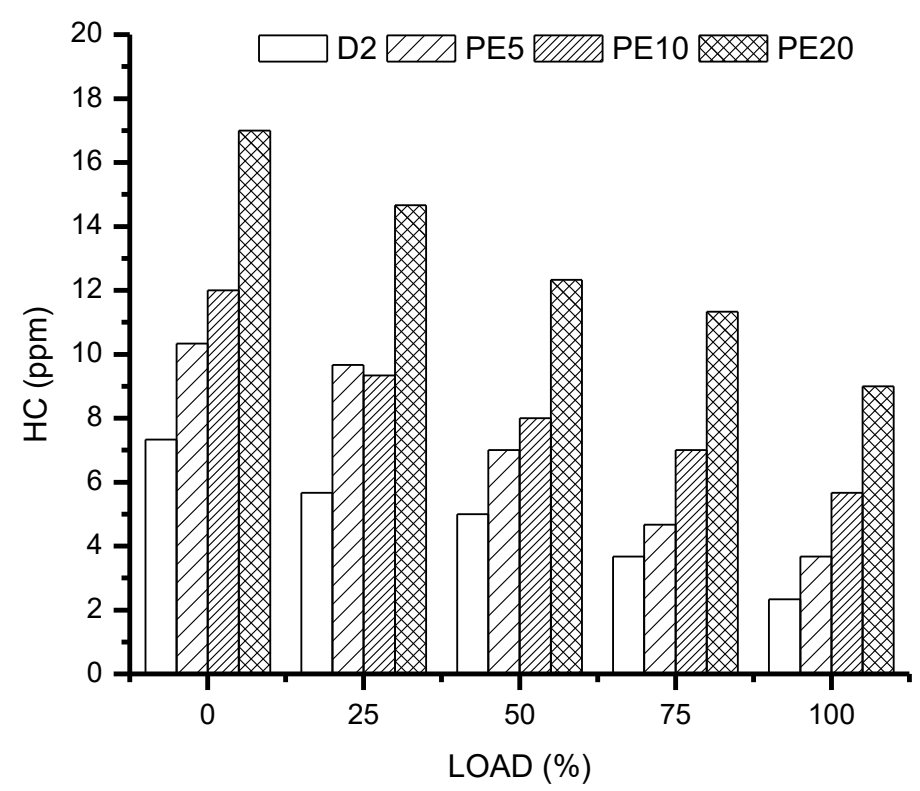

Figure 7: HC emission versus engine load for diesel fuel and fuel blends.

\section{Nitrogen oxides $\left(\mathrm{NO}_{x}\right)$ emission}

The effect of pentanol addition on $\mathrm{NO}_{\mathrm{x}}$ emission is shown in Figure 8. $\mathrm{NO}_{\mathrm{x}}$ emission is usually produced at high temperature during fuel combustion. Referring to the graph when engine load increases, $\mathrm{NO}_{\mathrm{x}}$ emission also increases for all fuel blends. At low engine load (25\%), $\mathrm{NO}_{x}$ decreased for PE5 and PE20 by $0.78 \%$, and $0.94 \%$, respectively, but $\mathrm{PE} 10$ increased by $0.62 \%$. However, the $\mathrm{NO}_{\mathrm{x}}$ formation trend fluctuated at high engine load $(100 \%), \mathrm{NO}_{\mathrm{x}}$ formation reduced by $0.81 \%$ for PE5, slightly increased by $0.19 \%$ for PE10 and decreased by $0.08 \%$ for PE20. At low engine load (25\%) and high engine load $(100 \%)$ there were no noticeable difference in $\mathrm{NO}_{\mathrm{x}}$ emission in all fuel blends compared to DF.

The main factor for the low $\mathrm{NO}_{\mathrm{x}}$ emission produced from the fuel blends combustion is that fuel blends have a high latent heat of vaporisation and high oxygen content compared to DF. Hence, both factors help to reduce the in-cylinder gas temperature during combustion [11]. The study concludes that the pentanol content of oxygen supports $\mathrm{NO}_{\mathrm{x}}$ formation, whereas at high load, the longer ignition delay associated with increasing n-pentanol leads to higher $\mathrm{NO}_{\mathrm{x}}$ emission. 


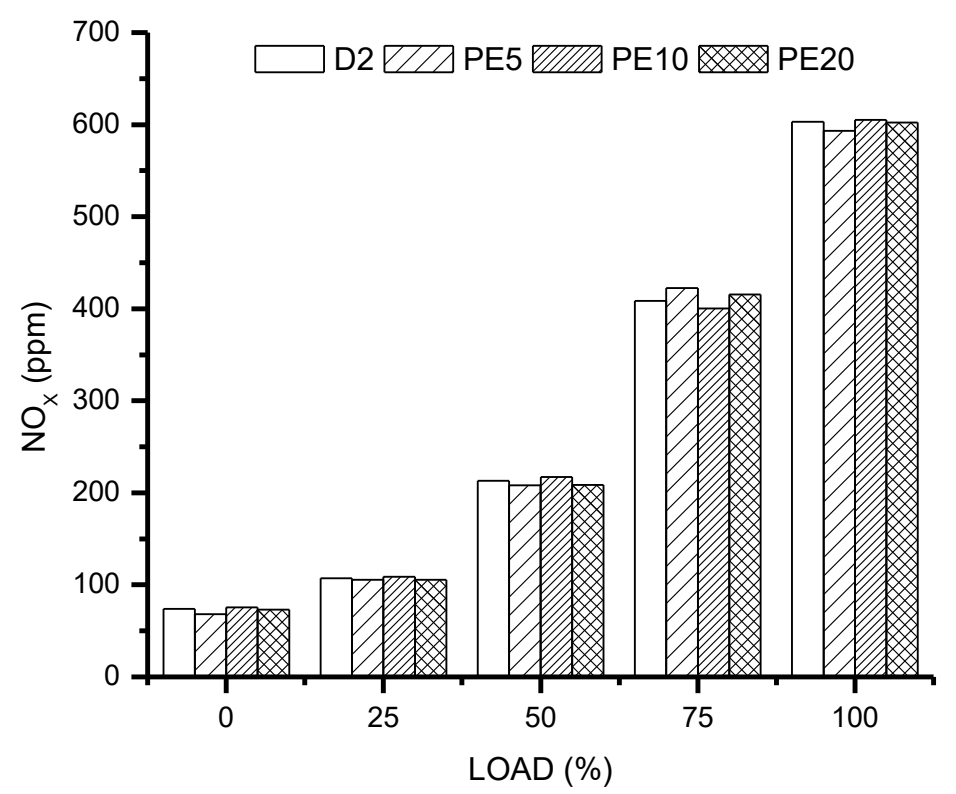

Figure 8. $\mathrm{NO}_{\mathrm{x}}$ emission versus engine load for diesel fuel and fuel blends.

\section{CONCLUSION}

This present study was designed to determine the effect of fuel thermo-physical properties, combustion characteristics, engine performance and exhaust emissions of DF with pentanol-diesel fuel blends PE5, PE10, and PE20. The results of the experiments are summarised as follows:

i. Thermo-physical properties such as calorific value, density, and kinematic viscosity reduced by $8.12 \%, 1.20 \%$, and $12.00 \%$, respectively, for PE20.

ii. The maximum reduction of in-cylinder pressure shown by PE20 with $6.54 \%$ decreased at low engine load $(25 \%)$ due to the lower density and kinematic viscosity by $0.822 \mathrm{~kg} / \mathrm{m}^{3}$ and $3.08 \mathrm{~mm}^{2} / \mathrm{s}$, respectively.

iii. At $2^{\circ} \mathrm{CA}, \mathrm{HRR}$ for PE20 was higher by $80.02 \%$ at high engine load $(100 \%)$ due to the increase of the percentage concentration of pentanol that enriched the oxygen content.

iv. $\quad \mathrm{CO}$ emission was reduced by $9.99 \%$ for PE20 at high engine load (100\%) due to the enrichment oxygen content in pentanol and good atomisation process.

v. $\mathrm{NO}_{\mathrm{x}}$ emission was reduced by $0.78 \%$ and $0.94 \%$ for PE5 and PE20, respectively, at low engine load (25\%).

The results show evidence that long-chain alcohol is a potential additive to be blended with DF to improve BSFC and BTE. Moreover, an addition of pentanol can effectively reduce emissions without serious impact on the test engine.

\section{ACKNOWLEDGMENT}

The authors would like to acknowledge the support of the Power Engine Lab, Faculty of Mechanical Engineering, of University Malaysia Pahang. This work was partly supported by UMP Research Grant Scheme PGRS180361. 


\section{REFERENCES}

[1] Kurani KS, Sperling D. Rise and fall of diesel cars: a consumer choice analysis. Transportation Research Record. 1988;1175:23-32.

[2] Alahmer A, Yamin J, Sakhrieh A, Hamdan M. Engine performance using emulsified diesel fuel. Energy Conversion and Management. 2010;51:1708-13.

[3] Hasannuddin A, Wira J, Sarah S, Ahmad M, Aizam S, Aiman M, et al. Durability studies of single cylinder diesel engine running on emulsion fuel. Energy. 2016;94:557-68.

[4] Yun H, Choi K, Lee CS. Effects of biobutanol and biobutanol-diesel blends on combustion and emission characteristics in a passenger car diesel engine with pilot injection strategies. Energy Conversion and Management. 2016;111:79-88.

[5] Zhang T, Munch K, Denbratt I. An Experimental Study on the Use of Butanol or Octanol Blends in a Heavy Duty Diesel Engine. SAE International Journal of Fuels and Lubricants. 2015;8:610-21.

[6] Altaie MAH, Janius RB, Rashid U, Taufiq-Yap YH, Yunus R, Zakaria R, et al. Performance and exhaust emission characteristics of direct-injection diesel engine fueled with enriched biodiesel. Energy Conversion and Management. 2015;106:365-72.

[7] Mahgoub B, Hassan S, Sulaiman S, Mamat R, Adam AA, Hagos FY. Dual fuel combustion in a ci engine powered by blended diesel-biodiesel fuel and simulated gasification gas. ARPN J Eng Appl Sci. 2016;11:22.

[8] Li L, Wang J, Wang Z, Xiao J. Combustion and emission characteristics of diesel engine fueled with diesel/biodiesel/pentanol fuel blends. Fuel. 2015;156:211-8.

[9] Othman MF, Adam A, Najafi G, Mamat R. Green fuel as alternative fuel for diesel engine: A review. Renewable and Sustainable Energy Reviews. 2017;80:694-709.

[10] Adam A, Ramlan NA, Jaharudin NF, Hamzah H, Othman MF, Mrwan AAG. Analysis of combustion characteristics, engine performance and exhaust emissions of diesel engine fueled with upgraded waste source fuel. International Journal of Hydrogen Energy. 2017;42:17993-8004.

[11] De Poures MV, Sathiyagnanam A, Rana D, Kumar BR, Saravanan S. 1-Hexanol as a sustainable biofuel in DI diesel engines and its effect on combustion and emissions under the influence of injection timing and exhaust gas recirculation (EGR). Applied Thermal Engineering. 2017;113:1505-13.

[12] Banapurmath N, Khandal S, Swamy RL, Chandrashekar T. Alcohol (ethanol and diethyl ethyl ether)-diesel blended fuels for diesel engine applications-a feasible solution. Advances in Automobile Engineering. 2015;4:1.

[13] Rashedul H, Masjuki H, Kalam M, Ashraful A, Rahman SA, Shahir S. The effect of additives on properties, performance and emission of biodiesel fuelled compression ignition engine. Energy Conversion and Management. 2014;88:34864.

[14] Rakopoulos DC, Rakopoulos CD, Giakoumis EG, Dimaratos AM, Kyritsis DC. Effects of butanol-diesel fuel blends on the performance and emissions of a highspeed DI diesel engine. Energy Conversion and Management. 2010;51:1989-97.

[15] Taghizadeh-Alisaraei A, Rezaei-Asl A. The effect of added ethanol to diesel fuel on performance, vibration, combustion and knocking of a CI engine. Fuel. 2016;185:718-33. 
[16] Ileri E, Atmanli A, Yilmaz N. Comparative analyses of n-butanol-rapeseed oildiesel blend with biodiesel, diesel and biodiesel-diesel fuels in a turbocharged direct injection diesel engine. Journal of the Energy Institute. 2016;89:586-93.

[17] Li F, Yi B, Fu W, Song L, Liu T, Hu H, et al. Experimental study on spray characteristics of long-chain alcohol-diesel fuels in a constant volume chamber. Journal of the Energy Institute. 2017.

[18] Campos-Fernandez J, Arnal JM, Gomez J, Lacalle N, Dorado MP. Performance tests of a diesel engine fueled with pentanol/diesel fuel blends. Fuel. 2013;107:866-72.

[19] Wei L, Cheung C, Huang Z. Effect of n-pentanol addition on the combustion, performance and emission characteristics of a direct-injection diesel engine. Energy. 2014;70:172-80.

[20] Rajesh Kumar B, Saravanan S, Rana D, Anish V, Nagendran A. Effect of a sustainable biofuel - n-octanol - on the combustion, performance and emissions of a DI diesel engine under naturally aspirated and exhaust gas recirculation (EGR) modes. Energy Conversion and Management. 2016;118:275-86.

[21] Saravanan S. Effect of exhaust gas recirculation (EGR) on performance and emissions of a constant speed DI diesel engine fueled with pentanol/diesel blends. Fuel. 2015;160:217-26.

[22] Imdadul HK, Masjuki HH, Kalam MA, Zulkifli NWM, Alabdulkarem A, Rashed MM, et al. Higher alcohol-biodiesel-diesel blends: An approach for improving the performance, emission, and combustion of a light-duty diesel engine. Energy Conversion and Management. 2016;111:174-85.

[23] Balamurugan T, Nalini R. Effect of blending alcohol with diesel on performance, combustion and emission characteristics of four stroke diesel engine-an experimental study. International Journal of ChemTech Research. 2014;6:750-62.

[24] Sathiyamoorthi R, Sankaranarayanan G. The effects of using ethanol as additive on the combustion and emissions of a direct injection diesel engine fuelled with neat lemongrass oil-diesel fuel blend. Renewable Energy. 2017;101:747-56.

[25] He B-Q, Shuai S-J, Wang J-X, He H. The effect of ethanol blended diesel fuels on emissions from a diesel engine. Atmospheric Environment. 2003;37:4965-71.

[26] Lapuerta M, Rodríguez-Fernández J, Fernández-Rodríguez D, Patiño-Camino R. Modeling viscosity of butanol and ethanol blends with diesel and biodiesel fuels. Fuel. 2017;199:332-8.

[27] Sundar RC, Saravanan G. Influence of hexanol-diesel blends on constant speed diesel engine. Thermal Science. 2011;15:1215-22.

[28] Suhaimi H, Adam A, Mrwan AG, Abdullah Z, Othman MF, Kamaruzzaman MK, et al. Analysis of combustion characteristics, engine performances and emissions of long-chain alcohol-diesel fuel blends. Fuel. 2018;220:682-91.

[29] Yao M, Wang H, Zheng Z, Yue Y. Experimental study of n-butanol additive and multi-injection on HD diesel engine performance and emissions. Fuel. 2010;89:2191-201.

[30] Phoon L, Mustaffa A, Hashim H, Mat R, Manan Z, Yunus N. Performance and emission characteristics of green diesel blends containing diethyl-succinate and 1-octanol. Journal of Cleaner Production. 2017;161:1192-202.

[31] Machacon HT, Shiga S, Karasawa T, Nakamura H. Performance and emission characteristics of a diesel engine fueled with coconut oil-diesel fuel blend. Biomass and bioenergy. 2001;20:63-9. 
[32] Rakopoulos D, Rakopoulos C, Kakaras E, Giakoumis E. Effects of ethanol-diesel fuel blends on the performance and exhaust emissions of heavy duty DI diesel engine. Energy Conversion and Management. 2008;49:3155-62.

[33] Cheung CS, Di Y, Huang Z. Experimental investigation of regulated and unregulated emissions from a diesel engine fueled with ultralow-sulfur diesel fuel blended with ethanol and dodecanol. Atmospheric Environment. 2008;42:884351 . 